\title{
The Frequency of Restless Legs Syndrome and Its Relationship with the Level of Addiction in Smokers
}

\section{Sigara İçen Bireylerde Huzursuz Bacaklar Sendromu Sıklığı ve Bağımlılık Düzeyi ile İlişkisi}

\author{
(D) Osman GÜLER ${ }^{1}$, id Sibel TUNÇ KARAMAN², iD Okcan BASAT² \\ 1Bozova District State Hospital, Family Medicine, Şanlıurfa, Turkey \\ 2University of Health Sciences Turkey, Gaziosmanpaşa Training and Research Hospital, Family Medicine, İstanbul, Turkey
}

\section{ABSTRACT}

Objective: In this study; it was aimed to determine the frequency of Restless Legs Syndrome (RLS) in smokers and to investigate the relationship with the level of addiction.

Methods: This prospective study was designed as a descriptive and single-centered study. Following the ethics committee's approval, the study was conducted with the smokers who applied to a tertiary hospital for any reason between 01/03/2017 and 01/07/2017. The Restless legs syndrome diagnosis form consisting of the International Restless Leg Syndrome Study Group (IRLSSG) consensus criteria was applied to all cases. Those who had all five criteria were diagnosed with RLS. The Fagerström Test for Nicotine Dependence (FTND) was applied to evaluate the nicotine addiction of the participants. Significance was accepted at the level of $\mathrm{p}<0.05$.

Results: Most of the 3,011 people included in the study were male $(52.3 \% ; n=1.579)$. According to the FTND, 68.4\% ( $\mathrm{n}=2.059)$ of the participants had medium and high dependence levels. RLS was detected in $9.8 \%(\mathrm{n}=296)$ of all participants. While the presence of RLS was $6.9 \%(n=66)$ in the group with a low level of dependence, it was found to be $11.2 \%(n=230)$ in the group with a mediumhigh level of dependence and this difference was found statistically significant $(\mathrm{p}=0.02)$.

Conclusion: In this study, the rate of RLS was found to be higher in smokers than the general population, and it was found that the incidence of RLS increased as the level of addiction increased.

Keywords: Cigarette, fagerström test for nicotine dependence, restless legs syndrome, smoking

\section{ÖZ}

Amaç: Bu çalışmada; sigara içenlerde huzursuz bacaklar sendromu (HBS) görülme sıklığının belirlenmesi ve bağımlılık derecesi ile ilişkisinin araştırılması amaçlandı.

Yöntemler: Bu prospektif çalışma, tanımlayıcı ve tek merkezli bir çalışma olarak tasarlandı. Çalışma etik kurul onayı alındıktan sonra; 01/03/2017 ile 01/07/2017 tarihleri arasında herhangi bir nedenle üçüncü basamak bir hastaneye başvuran sigara içicileri ile yapıldı. Tüm olgulara Uluslararası Huzursuz Bacaklar Sendromu Çalışma Grubu (IRLSSG) tarafindan geliştirilen huzursuz bacaklar tanı formu uygulandı. Beş kriterin tamamına sahip olanlara HBS tanısı konuldu. Katılımcıların nikotin bağımlıklarını değerlendirmek için Fagerström Nikotin Bağımlılık Testi (FNBT) uygulandı. Anlamlılık $\mathrm{p}<0,05$ düzeyinde kabul edildi.

Bulgular: Çalışmaya dahil edilen 3011 kişinin çoğu erkek (\%52,3; $\mathrm{n}=1,579)$ idi. FNBT'ye göre katılımcıların \%68,4’ü $(\mathrm{n}=2,059)$ orta ve yüksek derecede bağımlı idi. Toplamda tüm katılımcıların \%9,8'inde ( $\mathrm{n}=296)$ HBS saptandı. Düşük derecede bağımlılığı olan grupta HBS varlığı \%6,9 ( $\mathrm{n}=66)$ iken orta-yüksek derecede bağımlılığı olan grupta \%11,2 $(\mathrm{n}=230)$ bulundu ve aradaki bu farklılık istatistiksel olarak anlamlı bulundu $(\mathrm{p}=0,02)$.

Sonuç: Bu çalışmada, sigara içenlerde HBS görülme oranı genel popülasyona göre yüksek bulunmuş olup bağımlılık düzeyi arttıkça HBS görülme sıklığının arttığı saptandı.

Anahtar Sözcükler: Fagerström nikotin bağımlılık testi, huzursuz bacaklar sendromu, sigara, sigara içme

Address for Correspondence: Sibel TUNÇ KARAMAN, University of Health Sciences Turkey, Gaziosmanpaşa Training and Research Hospital, Family Medicine, istanbul, Turkey E-mail: drsibeltunc@hotmail.com ORCID ID: orcid.org/0000-0003-1133-8758 


\section{Introduction}

Restless leg syndrome (RLS) is a neurological disorder characterized by an abnormal sensation and dysesthesia in the extremities, especially in the legs. It is characterized by motor restlessness, periodic limb movements, and sleep disturbance, mostly occurring during rest or at night, partially or temporarily disappearing with activity and can be seen at any age $(1,2)$. Sir Thomas Willis made the first definition of RLS in 1685, and in 1945, it was named "RLS" by Ekbom $(3,4)$. The prevalence of RLS was reported as $1-15 \%$ worldwide, while in Turkey was reported to be $2.5-7 \%(5-7)$.

RLS has two clinical forms as primary (idiopathic) and secondary. RLS, not caused by another disorder, is called Idiopathic RLS. The other form that develops due to iron deficiency, pregnancy, obesity, low iron level, use of certain medications, such as antidepressants, neuropathy or smoking is called secondary RLS $(8,9)$. There is no specific diagnostic test for RLS, so diagnosis is made based on diagnostic criteria. All five key criteria determined by the International RLS Study Group (IRLSSG) must be observed for a definitive diagnosis (8). There are non-pharmacological and pharmacological approaches in the treatment of RLS. Dopamine agonists, alpha 2-delta ligands and opioids should be considered in pharmacological treatment, especially to reduce symptoms in moderate to severe primary RLS (10-12).

Smoking results in severe illnesses and deaths and is defined as the most critical public health problem by the World Health Organization (WHO). Approximately $19.9 \%$ of the entire population, over 15 years of age, was found to smoke worldwide (13). In our country, the smoking rate in the general population is approximately $27.5 \%(14)$.

In the literature, various studies have reported a significant relationship between smoking and RLS (15-19). To our knowledge, although there are studies on the rate of smoking and the effect of smoking on the severity of the disease in those with RLS, there are not many studies showing the relationship between RLS and level of addiction in smokers.

This study aimed to determine the frequency of RLS in smokers and the relationship of the frequency with the level of addiction.

\section{Methods}

This study was designed as a prospective, descriptive and singlecentered study. After the ethics committee's approval, the study was conducted between 01/03/2017 and 01/07/2017 in a tertiary hospital. Smokers who applied to the hospital for any reason were included in the study. The patients with polyneuropathy, pregnants, those who use SSRI, lithium, antiepileptic, antihistamine, antidopaminergic drugs, and individuals with physical and mental communication problems were excluded from the study. Participants were informed about the purpose of the study before being included in it.

\section{Data Collection Tools}

After obtaining the participants' verbal consent, their sociodemographic data and health status were interrogated by the face-to-face interview technique. Fagerström Test for Nicotine Dependence (FTND) was applied to all cases to evaluate their nicotine dependence. The scoring was as follows in this test consisting of 6 questions: $0-3$ as a low level of dependence, 4-6 as a medium level of dependence, and 7-10 as a high level of dependence.

Besides, all participants were tested with the Restless Leg Diagnosis Form developed by the IRLSSG. Those who had all five criteria in the diagnostic form were diagnosed with RLS. The results were recorded.

\section{Statistical Analysis}

Average and standard deviation, frequency and ratio values were used to analyze the obtained numerical data, and the chi-square test was used in the analysis of the qualitative data. Significance was accepted at the level of $\mathrm{p}<0.05$. The analyzes were done using NCSS 10 (2015. Kaysville, Utah, USA) software program.

\section{Results}

Three thousand eleven people were included in the study, most of whom were male $(52.3 \% ; \mathrm{n}=1,579)$. The participants' ages ranged between 18 and 70 , and the mean age was $39 \pm 11.49$. Most of the participants were between the ages of $35-49$ (44.8\%, $\mathrm{n}=1,353)$.

In total, RLS ( $\mathrm{n}=296)$ was found in $9.8 \%$ of all participants. As shown in Table 1, $55.4 \%(\mathrm{n}=164)$ of those with RLS were female and $44.6 \%(n=132)$ were male. This difference between gender was found to be statistically significant $(\mathrm{p}=0.04)$ (Table $1)$.

According to FTND, while the level of nicotine dependence was low in $31.6 \%(n=952)$ of the participants, $68.4 \%(n=2,059)$

Table 1. The distribution of RLS according to patients' gender

RLS (+)

(n=296; 9.8\%)

\begin{tabular}{|c|c|c|}
\hline Gender & $\mathrm{N}$ & $\%$ \\
\hline $\begin{array}{l}\text { Male } \\
(n=1,579 ; 52.3 \%)\end{array}$ & 132 & 44.6 \\
\hline $\begin{array}{l}\text { Female } \\
(n=1,432 ; 47.7 \%)\end{array}$ & 164 & 55.4 \\
\hline
\end{tabular}

RLS (-)

( $n=2715 ; 90.2 \%)$

$\mathrm{N}$

1447

1268
P*

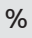

53.3

0.04 
were medium and high. While 22.3\% $(n=66)$ of the participants with RLS had low level of addiction, $77.7 \%(n=230)$ of them had medium-high level of addiction. It was determined that the incidence of RLS increased as the dependency increased, which was found statistically significant $(\mathrm{p}=0.02)$. Table 2 presents the differences in the RLS status of participants according to the level of addiction (Table 2).

The prevalence of RLS in smokers was $8.2 \%$ in the $18-34$ age group $(n=88), 9.6 \%$ in the $35-49$ age group $(n=130), 11.8 \%$ in the 50-64 age group $(n=62)$, and $25.8 \%(n=16)$ at the age 65 and over.

While $18.2 \%$ of the participants with RLS had a family history $(n=54), 9.0 \%$ of those without RLS had a family history $(n=244)$. The rate of family history in the RLS group was significantly higher than the group without RLS ( $\mathrm{p}<0.001)$.

The mean age $(34.4 \pm 15.2$ years) of the participants with RLS with a family history was lower than the average of those without a family history $(37.9 \pm 14.7$ years), and this difference between the ages in groups was found statistically significant $(\mathrm{p}=0.05)$.

\section{Discussion}

RLS is one of the less-known but common diseases and remains untreated for a long time. In recent years, there has been an increase in studies investigating the RLS. In this study, the frequency of RLS was found higher in smokers than the general population, and the incidence of RLS increased as the level of addiction increased. Female gender, advanced age, family history were also determined as risk factors for RLS in smokers.

In previous studies, RLS has been shown to be more common in women than in men. Park et al. showed that the prevalence of RLS was twice higher in women than in men (20). In the study conducted by Tasdemir et al. (10), the disease was reported to be 3.5 times more common in women than in men, and the prevalence increased proportionally with age. In our study, the prevalence of RLS in smokers was found to be higher in women, which was similar to that in the general population. Therefore, our results were compatible with other studies in the literature.

In the literature, the relationship between age and RLS is not certain. Some studies reported that RLS increases with age (21), while some reported that RLS increases the rate up to the age of 60 years and then decreases with increasing age (10). On the contrary, some studies found that prevalence did not increase with age (22). For example, Cho et al. (23) reported that the disease increased with age; most of them started before the age of 45 , peaked at the age of 50-59 and reached $9.1 \%$ in this age group. In our study, it was found that there was a significant relationship between the prevalence of RLS and age in accordance with some studies in the literature.

In previous studies, it was observed that most people with RLS had a history of RLS in at least one family member, and it was emphasized that the age of onset of the disease was early in people with a positive family history (24). The age of onset of RLS was found bimodal; it has been suggested that the form with an early onset is associated with familial factors, and the RLS form with late-onset is associated with secondary factors (25). In another study, the rate of family history in person with RLS was found to be $28.3 \%$ (26). In our study, family history was found in $18.2 \%$ of the participants with RLS. The mean age of those with RLS with a family history was found to be significantly lower than the average age of those without a family history, and these findings were consistent with the literature.

The prevalence of RLS has varied in studies using the IRLSSG criteria without addressing differential diagnoses. Vogl et al. (27) found that the prevalence of RLS was $8.9 \%$, Berger et al. (17); 10.6\%; Allen et al. (28);7.2\%.

In this study, we evaluated the frequency of RLS in smokers by using the IRLSSG criteria without mentioning the differential diagnosis, and RLS prevalence was found as $9.8 \%$. This rate was higher than the general population-prevalence studies conducted in Turkey. This high rate supported the fact that smoking has been a risk factor for RLS.

Although some studies reported the existence of a significant relationship between smoking and RLS, some studies provided the opposite data $(21,29)$.

In the study conducted by Phillips et al. (15), it was found that there was a significant relationship between smoking at least 20 cigarettes daily and RLS, but no significant relationship was observed between less than 20 cigarettes and RLS. In another study, it was determined that $44.7 \%$ of patients diagnosed with RLS smoked, and $73.9 \%$ of them smoked more than ten cigarettes per day. Active smokers were found to be significantly higher in the patient group than in the control group, and smokers of more than ten cigarettes per day were more likely to have RLS (16). It was also observed a significant relationship between smoking and RLS in the study conducted by Liu et al. (30).

Table 2. Evaluation of RLS status according to the level of addiction

\begin{tabular}{|c|c|c|c|c|c|c|c|}
\hline \multirow[b]{2}{*}{ Level of dependence } & \multicolumn{2}{|c|}{$\begin{array}{l}\operatorname{RLS}(-) \\
(n=2,715 ; 90.2 \%)\end{array}$} & \multicolumn{2}{|c|}{$\begin{array}{l}\text { RLS (+) } \\
(n=296 ; 9.8 \%)\end{array}$} & \multicolumn{2}{|c|}{$\begin{array}{l}\text { Total } \\
(n=3,011)\end{array}$} & \multirow{3}{*}{$\begin{array}{l}\mathrm{p}^{*} \\
0.02\end{array}$} \\
\hline & $\mathrm{N}$ & $\%$ & $\mathrm{~N}$ & $\%$ & $\mathrm{~N}$ & $\%$ & \\
\hline Low & 886 & 32.7 & 66 & 22.3 & 952 & 31.6 & \\
\hline Medium-high & 1,829 & 67.3 & 230 & 77.7 & 2059 & 68.4 & \\
\hline
\end{tabular}


In another study, compared to those who have never smoked, those who reported currently smoking more than 15 pieces have been shown to have an increased risk of RLS. However, this relationship was found only in women. In contrast, no significant association was noted between smoking and the risk of RLS among men in this study (31). Similar to this study, we also found that the female gender is a risk factor for RLS.

Unless the results obtained from these studies, in an epidemiological study searching for the association between RLS and cardiovascular disease, no differences were observed in the percentages of current and former smokers between subjects with or without RLS (32). In one of the studies conducted in our country, Ceylan et al. (33) found that $28 \%$ of patients with RLS were smokers, but the rate was also not significant compared to non-smokers. Similarly, in another study, no difference was found in terms of smoking when the RLS group was compared with the control group (34).

In our study, as a contribution to all these studies in the literature, which yielded different results regarding the relationship between smoking and RLS, we evaluated the addiction levels of smokers, in addition to smoking status, and found that the rate of RLS was higher in those with high addiction levels.

As is known, smoking increases symptoms in RLS. In a study conducted in the USA, patients were divided into two groups according to the frequency of RLS, and the rate of smoking was found higher in the group experiencing frequent symptoms. However, although at least 20 cigarette smoking per day was found to have a significant relationship with RLS symptoms, this relationship had not been detected in smokers who smoke less than 20 cigarettes (24).

Oksenberg (35) reported that a 75-year-old woman who smoked 25 cigarettes daily for 50 years had a decrease in RLS symptoms by sudden cessation of smoking. In a study investigating the relationship between RLS and smoking by Dündar (18), it was observed that smoking and RLS severity were directly related. In another study by Didriksen et al. (19), the relationship between RLS severity and cigarette consumption was observed. In our study, we examined the prevalence and the frequency of RLS in smokers, but not the effect of smoking on RLS severity, and we found that the frequency of RLS was higher in smokers than the general population. The results of our study are mostly similar to the literature.

\section{Study Limitations}

While collecting the participants' data, scales reporting personal status were used by the face-to-face interview technique. This condition could lead to individual prejudices, and individuals may not share accurate information.

The strengths of the study were that there are not many studies that reveal the relationship between RLS and level of addiction in smokers in the literature.

\section{Conclusion}

In this study, we concluded that the RLS frequency was higher in smokers than in the general population. Our study highlighted the potential impact of high levels of addiction on RLS as well as smoking status in smokers. In those who describe symptoms of restless legs syndrome, smoking status and level of addiction should be investigated. Large-scale studies are needed to examine the causal relationship between smoking and the development of RLS.

\section{Ethics}

Ethics Committee Approval: After the ethics committee's approval, the study was conducted between 01/03/2017 and $01 / 07 / 2017$ in a tertiary hospital.

Informed Consent: Smokers who applied to the hospital for any reason were included in the study.

Peer-review: Externally peer reviewed.

\section{Authorship Contributions}

Surgical and Medical Practices: O.G., O.B., Concept: O.G., O.B.,Design: O.G., O.B., Data Collection or Processing: O.G., Analysis or Interpretation: O.G., S.T.K., O.B., Literature Search: O.G., S.T.K., O.B., Writing: O.G., S.T.K., O.B.

Conflict of Interest: No conflict of interest was declared by the authors.

Financial Disclosure: The authors declared that this study received no financial support.

\section{References}

1. Garcia-Borreguero D, Williams A-M. An update on restless legs (Willis-Ekbomdisease): clinical features, pathogenezis and treatment. Curr Opin Neurol 2014;27:493-501.

2. Mungan S, Ozcan M, Orhan G, Titiz A, Arli B, Koseoglu S, et al. Clinical and polysomnographic features of patients with Restless Legs Syndrome. J Pak Med Assoc 2016;66:568-73.

3. Willis T. The London Practice of Physic. Bassett and Crook, London. 1685.

4. Ekbom KA. Restless legs: a clinical study. Acta Med Scand Suppl 1945;158:1-123.

5. Yilmaz K, Kilicaslan A, Aydin N, Kor D. Prevalence and correlates of restless legs syndrome in adolescents. Dev Med Child Neurol 2011;53:40-7.

6. Demir AU, Ardic S, Firat H, Karadeniz D, Aksu M, Ucar ZZ, et al. Prevalence of sleep disorders in the Turkish adult population epidemiology of sleep study. Sleep and Biological Rhytmes 2015;13:298-308.

7. Altunayoglu Cakmak V, Koc B, Nuhoglu I, Topbas M, Ucuncu SY, Deger O, et al. Prevalence of restless legs syndrome in Trabzon in the northeast Black Sea Region of Turkey: co-morbidities, socioeconomic factors and biochemical parameters. Neurol Res 2015;37:751-62. 
8. Allen RP, Picchietti DL, Garcia-Borreguero D, Ondo WG, Walters AS, Winkelman JW, et al. Restless legs syndrome/Willis-Ekbom disease diagnostic criteria: updated International Restless Legs Syndrome Study Group (IRLSSG) consensus criteria - history, rationale, description, and significance. Sleep Med 2014;15:860-73.

9. Sayin S, Atilla FD. Overlooked clinical presentation of iron deficiency; Restless Leg Syndrome. Ankara Med J. 2019;19-3.

10. Tasdemir M, Erdogan H, Börü UT, Dilaver E, Kumas A. Epidemiology of restless legs syndrome in Turkish adults on the western Black Sea coast of Turkey: A door to-door study in a rural area. Sleep Medicine 2010;11:82-6.

11. Manconi M, Ferri R, Zucconi M, Clemens S, Rundo F, Oldani A, et al. Effects of acute dopamine-agonist treatment in restless legs syndrome on heart rate variability during sleep. Sleep Med 2011;12:47-55.

12. Yalınay Dikmen P. Restless legs syndrome treatments in adults: practice guideline summary of American Academy of Neurology. Journal of Turkish Sleep Medicine 2017;4:59-64.

13. World health statistics overview 2019: monitoring health for the SDGs, sustainable development goals. Geneva: World Health Organization; 2019 (WHO/DAD/2019.1). Licence: CC BY-NC-SA 3.0 IGO.

14. WHO global report on trends in prevalence of tobacco smoking 20002025, second edition. Geneva: World Health Organization;2018.

15. Phillips B, Young T, Finn L, Asher K, Hening WA, Purvis C. Epidemiology of restless legs symptoms in adults. Arch Intern Med 2000;160:2137-41.

16. Sevim S, Dogu O, Kaleagasi H, Aral M, Metin O, Camdeviren H. Correlation of anxiety and depression symptoms in patients with restless legs syndrome: a population based survey, J Neurol Neurosurg Psychiatry 2004;75:226-30.

17. Berger K, Luedemann J, Trenkwalder C, John U, Kessler C. Sex and risk of RLS in the general population. Arch İntern Med 2004;164:196-202.

18. Dündar F. Huzursuz bacaklar sendromu ve sigara, Ankara Üniversitesi/ Tıp Fakültesi / Nöroloji Anabilim Dalı, 443683, 2016.

19. Didriksen M, Rigas AS, Allen RP, Burchell BJ, Di Angelantonio E, Nielsen $\mathrm{MH}$, et al. Prevalence of restless legs syndrome and associated factors in an otherwise healthy population: results from the Danish Blood Donor Study. Sleep Med 2017;36:55-61.

20. Park YM, Lee HJ, Kang SG, Choi HS, Choi JE, Cho JH, et al. Prevalence of idio-pathic and secondary restless legs syndrome in Korean women. Gen Hosp Psychiatry 2010;32:164-8.

21. Hadjigeorgiou GM, Stefanidis I, Dardiotis E, Aggellakis K, Sakkas GK, Xiromerisiou G, et al. Low RLS prevalence and awareness in central Greece: an epidemiological survey. Eur J Neurol. 2007;14:1275-80.

22. Benediktsdottir B, Janson C, Lindberg E, Arnardóttir ES, Olafsson I, Cook E, et al. Prevalence of restless legs syndrome among adults in
Iceland and Sweden: lung function, comorbidity, ferritin, biomarkers and quality of life. Sleep Med 2010;11:1043-8.

23. Cho YW, Shin WC, Yun CH, Hong SB, Kim JH, Allen RP, et al. Epidemiology of restless legs syndrome in Korean adults. Sleep 2008;31:219-23.

24. Phillips B, Hening W, Britz P, Mannino D. Prevalence and correlates of restless legs syndrome: results from the 2005 National Sleep Foundation Poll. Chest 2006;129:76-80.

25. Winkelmann J, Muller-Myhsok B, Wittchen HU, Hock B, Prager M, Pfi ster $\mathrm{H}$, et al. Complex seregation analysis of restless legs syndrome provides evidence for an autosomal dominant mode of inheritance in early age at onset families. Ann Neurol 2002;52:297-302.

26. Haba-Rubio J, Marti-Soler H, Marques-Vidal P, Tobback N, Andries $\mathrm{D}$, Preisig M, et al. Prevalence and determinants of periodic limb movements in the general population. Ann Neurol 2016;79:464-74.

27. Vogl FD, Pichler I, Adel S, Pinggera GK, Bracco S, De Grandi A, et al. Restless legs syndrome: epidemiological and clinicogenetic study in a South Tyrolean population isolate. Mov Disord. 2006;21:118995.

28. Allen RP, Walters AS, Montplaisir J, Hening W, Myers A, Bell TJ, et al. Restless Legs syndrome prevalance and impact: REST General Population Study. Arch Intern Med 2005;165:1286-92.

29. Sevim S, Dogu O, Camdeviren H, Bugdayci R, Sasmaz T, Kaleagasi $\mathrm{H}$, et al. Unexpectedly low prevalence and unusual characteristics of RLS in Mersin, Turkey. Neurology 2003;61:1562-9.

30. Liu Y, Liu G, Li L, Yang J, Ma S. Evaluation of cardiovascular risk factors and restless legs syndrome in women and men: A preliminary population-based study in China. J Clin Sleep Med 2018;14:445-50.

31. Batool-Anwar S, Li Y, De Vito K, Malhotra A, Winkelman J, Gao X. Lifestyle factors and risk of restless legs syndrome: prospective cohort study. J Clin Sleep Med 2016;12:187-94.

32. Winkelman JW, Shahar E, Sharief I, Gottlieb DJ. Association of restless legs syndrome and cardiovascular disease in the Sleep Heart Health Study. Neurology 2008;70:35-42.

33. Ceylan M, Aygül R, Yalçın A. Investigation of restless leg syndrome prevalence and assosiated sociodemographic features in province of Erzurum. J Contemp Med 2019;9:48-54.

34. Aydın Ş, Özdemir C, Sökücü SN.The Relationship Between Restless Legs Syndrome and Cardiovascular Risk Factors. Journal of Turkish Sleep Medicine 2019;1:29-36.

35. Oksenberg A. Alleviation of severe restless legs syndrome (RLS) symptoms by cigarette smoking. J Clin Sleep Med. 2010;6:489-90. 